\title{
DESIGN WITHOUT CAUSALITY: HEIDEGGER'S IMPOSSIBLE CHALLENGE FOR ECOLOGICALLY SUSTAINABLE
} ARCHITECTURE

\author{
GLEN HILL \\ Faculty of Architecture, Design and Planning \\ University of Sydney
}

NSW 2006, Australia

g.hill@arch.usyd.edu.au

\begin{abstract}
Deploying Martin Heidegger's thinking on technology, this paper attempts to show an internal contradiction inherent in our technologically oriented approach to sustainable design.

Heidegger's thinking on technology, which has had an influence both on the ecological movement and on architecture, situates the problematic shift toward modern technology at the beginning of the enlightenment with the emergence of new understandings of both the subject and the object. Each of these revolutionary understandings contribute to the reframing of nature as knowable and (therefore) controllable. Nature thus moves from a position of mystery and wonder to that of a disenchanted, predictable system, allowing the appearance of a technological orientation in which nature is framed in advance as something simply manipulable for our benefit.

Unlike the Classical Realist account of nature that emerged from the enlightenment separation of subject and object, Heidegger's formulation of the real, of nature, does not allow the same confidence in causality and control. However, design, as the engine of technological innovation in modernity, appears inseparable from the modern technological understanding of causality and control and the framing of nature as a mere resource. This problematises the possibility that design, as it is currently conceived, can contribute to achieving an ecological sustainable relation to nature.
\end{abstract}

Keywords: technology, Heidegger, ecological, sustainable, design.

\section{Introduction}

Any discussion of technology would be incomplete without consideration of the thinking of Martin Heidegger. His often-difficult formulations of the relation between modern technology and our life-world has informed quite diverse practical and theoretical trajectories. His work prepared the way for that branch of philosophy now referred to as the Philosophy of Technology (Ihde). His thinking on technology informed the radical counter practices of the early ecology movement, particularly 'Deep Ecology' (Naess). In architecture, Heidegger's thinking was deployed in theorisations of place and identity, popularised by the writings of Norberg-Schulz, 
and later in perhaps more considered ways by critical architectural theorists, such as Kenneth Frampton, in their attempt to formulate an architectural practice to counter the perceived globalising and homogenising tendencies of late modernity.

In this paper I want to return to a key aspect of Heidegger's thinking on technology, lay it out in relation to his broader critique of rationalism, and clarify, in a way that I believe has not been previously articulated, the profound ecological implications, particularly for the design professions, of Heidegger's critique of modern technology.

\section{Life-world and Earth}

For me, Heidegger's most revelatory contribution to philosophy centres on his insistent explication of the absence that grounds all presence. It is the power of the recognition of this absence that continues to shake any pretence of the possibility of rationalist foundations (in every domain, including architecture). The mapping of this absence over the course of his work followed a rambling philosophical path.

Since Descartes, philosophical explanations about how it is we can have knowledge of an object, had begun with two premises: a subject that is present to itself, and an object that is independently present. With this schism between self-present subject and ever-present object in place, the tradition was left to construct shaky explanatory bridges showing how a subject present in its own 'internal world' could have certain knowledge of an object present in an 'outside world'.

Heidegger's early work, most famously Being and Time, firstly undermines the priority given to a self-present subject. It shows that our noticing of something as something in the present is not on the basis of our being self aware subjects (thinking things), but on the basis of unnoticed experience of the everyday life-world of our past and an unnoticed projection of our everyday projects into the future. In other words, it shows how our absent past and absent projected future allows things come to presence as the present.

However, because its starting point was located in the everyday being of human beings, Heidegger's early work contained an anthropocentric bias. Within his work lurked the problematic implication that humanity, in this case human projects and practices, still determines the way the world comes to presence. To redress this implication, Heidegger deployed a great deal of his later work toward demonstrating that neither human subjectivity nor human projects and practices determine the way the world comes to presence.

Central to achieving this, Heidegger took the familiar concept of 'earth' and made it strange (Haar). On one reading, Heidegger's earth names the totality of the universe, nature, the real, before it is brought into our world as something for us. Importantly earth is never merely an object, a thing; it is instead the potential that shows up as things, objects, when brought into our world. But neither is world and earth a dichotomous pair. World is one disclosure of earth, but never its totality. Thus in opposition to the rationalist tradition, earth cannot be made entirely present. It is a potential that is only disclosed to us in its encounter with our particular practices and projects. Countering any implication of anthropocentrism, this disclosure is not a one-sided affair, dependent simply on our human projects and practices. Earth is a potentiality with its own force, its own trajectories, that struggles with the interpretive forces of our world that attempt to disclose it. Prior to its disclosure in our world, earth, as potential, is thus also an absence.

Considering his total oeuvre, then, Heidegger paints a profound and radical picture of struggle between two absences - the absence of the subject and the absence of the object - between which our world comes to presence.

\section{Regime of Modern Technology}

Heidegger's discussion of technology, particularly the danger of modern technology, may initially appear disconnected from his critique of the historical valorisation of the separation of self-present subjects and ever-present objects. The two however emerge as intimately intertwined.

In The Question Concerning Technology, Heidegger draws a distinction between modern and pre-modern technology. Heidegger points out that under the dominion of modern technology our relation with nature becomes one of demanding and challenging - a relation for which he uses the German neologism 'Ge-stell', sometimes translated as 'enframe' or 'set-up'. Rather than being open to what nature offers to us, nature is instead forced to reveal itself in ways we have formulated in advance. For Heidegger the essence of modern technology is thus its enframing 
or setting up of nature in terms of human interests to the extent that nature is revealed one dimensionally as a resource for human use.

To demonstrate this with an example from our contemporary context, it is evident that even the nature we believe we are defending from this very exploitation by designating reserves, parks and wilderness, is ultimately framed as having some anthropocentric purpose: to service the tourist industry, as a sink for green-house gases, to maintain biodiversity for some future medical, economic or human survival endpoint, and so on.

Scholars attempting to elucidate Heidegger's account of the process by which the modern technologised West comes to be enframed in this way, and how this relation to technology differs from the human-technology relation in the pre-modern world, draw upon particular moments in Heidegger's texts. Michael Zimmerman, who works meticulously through Heideggerian arguments with a focus on the ecological repercussions of technological enframement, highlights what he sees as the key mechanisms of enframing.

Beginning with the modern condition of subjects standing apart from objects, Zimmerman describes the steps that lead us to enframe and consume nature:

Heidegger defined human existence as the existential clearing in which the body, ego, feeling-states, memories, thoughts tools and natural things can appear. Tending to conceal that it exists as this clearing, Dasein becomes absorbed in its dealings with entities. This falling into the world and away from one's own being stems from the fact that Dasein's being is inherently mortal and finite. Indeed, the clearing that lets things be is in effect no-thing at all, but finite, mortal nothingness or openness. Forgetting this openness lets Dasein work unself-consciously with the instruments of everyday life, but such everyday forgetting can be aggravated when the mood of anxiety (angst) threatens to reveal Dasein's mortal nothingness. Fleeing from this disclosure, Dasein plunges into inauthenticity, which involves two related aspects. First, inauthentic Dasein conceives of itself as a stable, self-grounding subject, thus transforming Dasein's uncanny nothingness into a defendable thing: the ego-subject. To defend itself, the ego-subject sets out to control all entities. Second, since Dasein cannot succeed in turning itself into a fixed entity, inauthentic Dasein continues to experience a sense of existential lack or incompleteness. One way of overcoming this lack is to full up the self by consuming even more entities. Death-defying inauthentic Dasein, then, seeks to protect and complete itself by dominating other people and devouring the planet. (110-11)

I have a sense of unease with this and similar philosophical formulations of the emergence our anthropocentric exploitation of the planet. The steps in the argument do not appear entirely compelling. Why is control of all entities the necessary outcome of becoming a 'death-defying' ego-subject, and why should the subsequent existential lack necessarily lead us to consume entities $^{1}$ Also, in the one text where Heidegger painstakingly lays out the relation between our enframent by modern technology and its repercussions in terms of consumption of the planet The Question Concerning Technology — he does not mention our flight from mortality, which is a theme in other works. While it may be the background of the text, it is certainly not the thematic hinge he wants to emphasise. For me there is another understanding of Heidegger's text, that is not necessarily more correct, but is perhaps more revealing for design as its strives to achieve ecological sustainability.

\section{Causality in Modern Technology}

In The Question Concerning Technology, Heidegger makes the paradoxical claim that modern technology arrives before the appearance any actual modern technologies (22). Heiddegger's chronology appears to be: firstly the arrival of the essence of technology, then the arrival of both modern science and the appearance of modern technologies,

It is said that modern technology is something incomparably different from all earlier technologies because it is based on modern physics as an exact science. Meanwhile we have come to understand more clearly that the reverse holds true as well: Modern physics, as experimental, is dependent upon technical apparatus and upon the progress in the building of apparatus. The establishing of this mutual relation between technology and physics is correct. But it remains a merely historiographical establishing of facts and says nothing about that in which this mutual relationship is grounded. The decisive question still remains: Of what essence is modern technology that it happens to think of putting exact science to use? (14) 
The essence of modern technology that I contend Heidegger is trying to show now enframes us is the product of the shift that initiates modernity itself: the radical new understanding of the self, and the radical new conception of the nature of the very stuff that constitutes the universe. This shift has come to be summarised in the now rather innocuous phrase, the separation of subject and object.

As discussed at the outset of the paper, the separation of subject and object arrives with the privileging of an understanding of our relation to the world as one of a self-present subject located in a universe of ever-present objects. This understanding is evidenced in both the modern scientific apprehension of our universe, and our everyday apprehension of the world. For modern science, the entities that constitute the universe are a particular way (a position described as Classical Realism). Once it is understood that entities are a particular way, then it becomes possible that we can come to know the way they are - this is the orientation necessary to found modern science. In a more everyday context, when we reflect on our own relation to the world the entities around us appear in much the same way as they do for science - as objectively and permanently present. For Heidegger, such reflection is secondary to unreflective coping, but in modernity it has been taken as primary.

The consequence of the shift to our modern conception of self and world should not be underestimated. Understanding that the entities constituting our universe are a particular way (not flux, not transformable by whim of God, or so on), brings with it the conviction we can come to understand these entities, to understand nature as it were, and as a consequence that we can come to understand the causality inherent in nature. Heidegger spends a deal of time in The Question Concerning Technology discussing pre-modern and modern notions of causality. His assertion that 'wherever instrumentality reigns, there reigns causality' (6), identifies causality as being at the heart of our instrumental relation to nature. Clearly, it is a small step from the belief that we can understand causality in nature to the conviction that we can control it. Understanding causality and controlling causality can be seen as the twin origins of science and technology respectively.

\section{Design Hubris}

At this point, the implications for ecological sustainability and for design also become clear. With modernity's belief that causality in nature could be understood and therefore controlled, technologies have been increasingly deployed with the confidence that their outcomes can be predicted. While the design of each individual technologically mediated intervention would have been intended to cause a (local) beneficial outcome for some portion of humanity (grounded in 'care' in Heidegger's terms), their cumulative impact on the ecological systems of the planet is now considered by many to be potentially catastrophic. If this scenario is accepted, then design could be characterised as the well-intentioned engine driving the proliferation of technologies that now threatens the planet.

Designers, and not least architects, are enframed within a view of causality which instils confidence that designed outcomes have predictable effects. Tellingly, this confidence is no less evident in the responses to the perceived ecological crisis, where design is confidently being advocated to develop solutions to overcome the very problems that confident designing has created. Confirming such a view of the designer, Heidegger refers to the 'engineer in his drafting room' (which could equally be the architect in his/her studio) as being part of an enframed system, 'an executer, within Enframing' (Question, 29).

Modernity's understanding that the entities constituting our universe are $\underline{a}$ particular way and operate under the rule of causality, marks a momentous shift: in pre-modernity nature is apprehended as mysterious and marvellous; in modernity nature is apprehended as systematic and operable. This shift is, for me, no better illustrated than in the surreal (yet quite serious) design for a solar umbrella consisting of trillions of satellites launched from earth and intended to stop global warming (Brahic). The pre-modern understanding of the mystery and wonder of the sun's warmth granting life to all beings on earth (for many pre-modern cultures the sun and God were one), has shifted to a modern understanding where the sun's warming of the earth is a calculable system that we do not merely believe we can understand, but have the hubris to believe that we can control.

\section{Design Humility}

Heidegger's conception of the real, evident in his own formulation of earth as absence, does not offer a foothold to causality in the same way as modernity's understanding of the real as 
presence. In The Question Concerning Technology, Heidegger refers approvingly to the work of Werner Heisenberg, whose formulation of Quantum Mechanics lays down a challenge to the Classical Realism of modern physics that is as radical as Heidegger's own challenge to traditional philosophical formulations of the real (23). For Heidegger, the real, earth, is not $\underline{a}$ particular way, and cannot therefore ground the sort of causality that allows the impacts of design outcomes to be anticipated. ${ }^{2}$ Thus Heidegger's critique of any generalisable causality, does not encourage intentional action through the vehicle of design (in all its meanings and domains) as it is traditionally conceived.

Perhaps because of this recognition, I cannot help but feel a sense of frustration in my encounter with Heidegger's thinking. This frustration is particularly evident to me in my role as a design studio tutor and coordinator of the sustainable stream of the senior design years of a professional architecture degree, where I have been unable to incorporate, in any meaningful way, Heidegger's radical stance. So-called ecologically sustainable design is invariably premised on the expectation that design interventions can be developed in which certain identified causes of the current environmental crisis can be ameliorated. The success of such interventions depends directly on causal chains, such as the relation between building energy use, green-house gas emissions and global warming. But when causality itself is universally challenged and all certainty relating to the outcome of a design intervention is removed, then confidence in the act of design is undermined and the effect immobilising.

Hesitation may be the reaction Heidegger would wish in the face of the recognition of the enframing of modern technology. To conclude The Question Concerning Technology Heidegger advocates an (active) non-action - articulated in his much-debated call to 'let be' as the appropriate response to the relentless demands of modern technology. Such an orientation is of course problematic in a studio context where it is completely mismatched to preframed expectations about design and architecture and their heroic role in inventing new worlds. Heidegger's conservative calls to focus on the 'little things' (Rojcewicz, 213ff), on life's everyday routines, run entirely counter to the innovative and radical attributes of design that are now valorised. But in the context of a world of unrelenting change driven by the vehicle of technologically mediated design, Heidegger's may indeed be the radical position. As Gianni Vattimo has pointed out, what designers proudly depict as innovation, has become nothing more than the maintenance of the ordinary,

....in a consumer society continual renewal (of clothes, tools, buildings) is already required physiologically for the system simply to survive. What is new is not in the least 'revolutionary' or subversive: it is what allows things to stay the same (7).

As if in a final dismissal of causality and the possibility of our control over it, Heidegger argues that we cannot even choose this course. Even if there were a recognition that the causality that governs design is flawed, and that the certainty sustaining our technological striving for the new is groundless, Heidegger does not allow that we have the power to direct such an outcome (Rojcewicz). To do so and expect a benign result would simply be another act of enframed designing. Our course, on Heidegger's account, is granted to us, not designed by us.

\section{Notes}

${ }^{1}$ The only line of reasoning I can propose to support such an argument would take the following course: that the separation of subject and object resulted in a normalised understanding of selfpresent subjects and ever-present objects. But the objects that constitute the universe, nature, are not in fact ever-present. Their (varying) appearances for us rely on their involvement in the shifting projects and practices of our world. From our side, there can be no firm ground for any object except the groundless ground of our world. Likewise there can be no firm ground to the nature of our own selves except in the groundless ground of our world. This apparently nihilistic formulation that is dependent on, and highlights our, worldedness (mortality), undermines the possibility that there is an ever-present object perceivable by self-present subjects. We therefore flee from contemplation of this nihilism by technologically facilitated consumption. Heidegger writes that "The emptiness of Being can never be filled up by the fullness of beings, especially when this emptiness can never be experienced as such, the only way to escape it is incessantly to arrange beings in the constant possibility of being ordered as the form of guaranteeing aimless activity. Viewed in this way, technology is the organization of a lack." Martin Heidegger. The End of Philosohy, trans. J. Stambaugh. New York: Harper and Row, 1973. P. 107. 
${ }^{2}$ In summary, causality can only operate within a specific world of technologically mediated projects and practices and not beyond it. As long as science, for example, can strictly maintain the parameters of a 'world' (through a replicable experimental set up for example) then predictability may be attainable. The obvious problem with any design intervention is that it transforms the very world in which the causally based prediction was developed. Because the real, earth, is not a particular way, new aspects of earth are revealed in the struggle between this new world and earth. Thus predictions made in the world in which the design was developed about the impacts that design may have, need not hold in the new world that the design itself brings into being. The long history of unanticipated outcomes of design interventions might be used as support for this view.

\section{References}

Brahic, Catherine. Solar Shield Could be Quick Fix for Global Warming. New ScientistTech 15:35 05 June 2007, NewScientist.com news service, http://.newscientist.com/article/dn11993. See also http://content.zdnet.com/2346-9595 2236394.html.

Haar, Michel. The Song of the Earth: Heidegger and the Grounds of the History of Being. translated by Reginald Lilly. Bloomington : Indiana University Press, 1993.

Heidegger, Martin. Being and Time. translated by John Macquarrie \& Edward Robinson. London : SCM Press, 1962.

Heidegger, Martin. The Question Concerning Technology and other essays. translated and with an introduction by William Lovitt. New York : Harper \& Row, 1977.

Ihde, Don. Philosophy of Technology : an Introduction. New York : Paragon House, 1993.

Næss, Arne. Ecology, Community, and Lifestyle : Outline of an Ecosophy. translated and revised by David Rothenberg. New York: Cambridge University Press, 1989.

Rojcewicz, Richard. The Gods and Technology: A Reading of Heidegger. Albany: State University of New York Press, 2006.

Vattimo, Gianni. The End of Modernity. Baltimore: Johns Hopkins University Press, 1985.

Zimmerman, Michael. Contesting Earth's Future: Radical Ecology and Postmodernity. Berkeley: University of California Press, 1994. 